\title{
IMPERTINÊNCIAS DA GESTÃO
}

O glamour da vida executiva é cantado em verso e prosa por revistas e jornais de negócios, livros de gestão, programas de televisão e filmes. Invariavelmente, os executivos aparecem como alguém poderoso e possuidor de todos os símbolos de status e prestígio social. São eles que pilotam carros de luxo e usam roupas e assessórios de grife. Habitantes de bairros nobres e frequentadores dos restaurantes e bares da moda, em larga medida os homens de negócios são apresentados como heróis e vencedores.

Nesse imaginário glamouroso, a vida corporativa e o trabalho nas grandes organizações aparecem como a ocupação profissional ideal e repleta de realizações, e surgem como caminho para o sucesso e a felicidade. Difundiu-se a ideia de que ser executivo equivale a ter sucesso e prestígio, e de que a vida no mundo dos negócios é uma das melhores coisas que um profissional pode querer.

E as escolas de administração tendem a reforçar essa imagem. Em larga medida, elas se calam para um lado não tão belo da realidade organizacional. Impera o silêncio a respeito da crescente intensificação do trabalho, da imposição de uma lógica de trabalho marcada pelo culto ao desempenho, das pressões psicológicas que os indivíduos sofrem no dia a dia das corporações, da proliferação de um trabalho sem con- teúdo e de inúmeros casos de abuso, entre outras mazelas do mundo das organizações. A angústia e o sofrimento presentes na vida executiva são jogados para baixo do tapete, nas versões dominantes a respeito do mundo empresarial.

Foi com o objetivo de discutir esses silêncios, angústias e problemas, que no segundo semestre de 2010 a FGV-EAESP iniciou as "Jornadas Impertinentes", um ciclo de palestras e debates voltado, principalmente, aos seus alunos de graduação. A impertinência da iniciativa reside, fundamentalmente, em querer trazer à tona questões que geralmente geram desconforto e que, exatamente por isso, são deixadas de lado pela maioria das escolas de administração. Nesse sentido, as Jornadas Impertinentes foram criadas também com o intuito de honrar uma tradição presente na FGV-EAESP: a reflexão crítica sobre as organizações no Brasil sempre foi uma marca distintiva do pensamento da instituição, e é um elemento central para formar líderes que não apenas aceitem o mundo à sua volta, mas que sejam capazes de transformar a realidade em que vivem.

Aos alunos, professores e demais membros da comunidade EAESP, fica o convite para fiquem atentos à programação e se juntem a nós nas próximas Jornadas.

\section{Difundiu-se a ideia de que ser executivo equivale a ter sucesso e prestígio, e de que a vida no mundo dos negócios é uma das melhores coisas que um profissional pode querer}

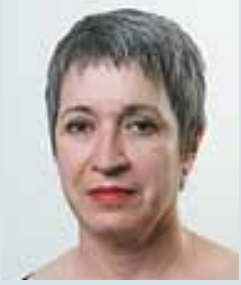

ROSA MARIA VIEIRA FGV-EAESP

rosa.vieira@fgv.br

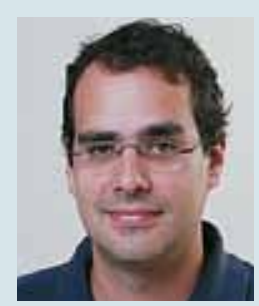

RAFAEL ALCADIPANI FGV-EAESP

rafael.alcadipani@fgv.br 